\title{
Laboratory Test and Calibration of Direct Paddy Drum Seeder for Pre- Germinated Paddy Seeds
}

\author{
Devesh Kumar ${ }^{1 *}$, Uday Veer Singh ${ }^{1}$, Jitendra Kumar ${ }^{2}$, Manish Kumar $^{1}$ and Kalay Khan ${ }^{1}$ \\ ${ }^{1}$ Department of Farm Machinery and Power Engineering, Sam Higginbottom University of \\ Agriculture, Technology and Sciences, Allahabad - 211007. (U.P.), India \\ ${ }^{2}$ J.L.N Polytechnic College Mahmudabad Sitapur, U.P., India \\ *Corresponding author
}

\begin{abstract}
Keywords
Paddy drum seeder, Calibration, Paddy seeds, Puddling, Germinated seeds.

Article Info

Accepted:

17 July 2017

Available Online:

10 September 2017 increasingly popular now days in India. The wet seeding of rice was adopted. Sprouted seeds were sown in puddle field 1-2 days after puddling using perforated drum seeder. Eight row direct paddy drum seeder tested manually drawn was used. The laboratory calibration was carried out with different combinations of drum fill level viz., full, half, quarter, and travel speed viz., $1 \mathrm{~km} / \mathrm{h}, 1.5 \mathrm{~km} / \mathrm{h}$ and $2 \mathrm{~km} / \mathrm{h}$. From the laboratory calibration test the combination of half drum fill level and $1 \mathrm{~km} / \mathrm{h}$ speed were selected for field evaluation of drum seeder. The drum seeder was tested on puddle field. It was found from the study that, the theoretical field capacity was found $0.16 \mathrm{ha} / \mathrm{h}$, while effective field capacity of the drum seeder was observed $0.131 \mathrm{ha} / \mathrm{h}$. The field efficiency of the seeder was found 82.08 percent. The number of seeds dropped per hill was 5 . The hill to hill spacing was $14.5 \mathrm{~cm}$. The number of hills per square $\mathrm{m}$ was 30 . The hill missing was 5.8 percent. The cost of operation of drum seeding is Rs. 42.67 per hour and Rs. 341.36 per ha. Seed rate was nearly constant for initial $10 \mathrm{~m}$ distance travelled. For the next successive points i.e. up to $20 \mathrm{~m}$ distance travelled seed rate was observed increasing continuously during actual field operation.
\end{abstract}

\section{A B S T R A C T}

Direct seeding and transplanting are the two methods of planting rice. The rice farmers practicing transplanting are facing problems like shortage of labour during peak time, hike in labour charges, small and fragmented land holdings etc. Direct seeding is becoming

\section{Introduction}

Rice one of the most important crop of India and occupies $23.3 \%$ of gross cropped area of the country. Rice contributes $43 \%$ of total grain production and $46 \%$ of total cereal production. India has largest area under rice crop and it is about 45 million hectares. The total rice growing area in Uttar Pradesh state is about 5.90 million hectares. Rice is grown in all the 72 districts of Uttar Pradesh with low to high acreage. The rice plant belongs to the genus Oryza of Gramineae family. Out of 24 species of rice only two species Oryza sativa and Oryza glaberrima are cultivated. Further sativa species is grouped in three sub species viz., indica, japonica, jaanica. The traditional method followed from many years in Allahabad region is transplanting of seedlings raised in nursery. Transplanting method involves seedbed preparation, nursery growing, care of seedlings in nursery, 
uprooting of seedlings, hauling and transplanting operations. The preparations of seedbed sowing are done 30 days before planting.

The seedbed area required is about 10 percent of main area of the field transplanting of paddy at right time is also important parameter. A delay in transplanting by one month reduces the yield of rice by 25 percent and delay by two months results in 70 percent reduction in yield (Khan and Majid 1989). Traditional transplanting method associated with problem of hike in labour charges, small and fragmented land holdings, lack of technical knowledge, non- availability of ample water and other inputs. To tackle all these problems direct seeding of rice has been found most appropriate alternative to transplanting. It not only avoids seedbed preparation, nursery raising and transplanting but also gives better yield than existing manual transplanting. The advantage of transplanting drum seeder is that row-row spacing can be easily maintained and dropping of seeds in hills is possible.

Lack of labour during peak periods of transplanting may cause delay in the operations. In such situations, the drum seeder is an effective mean for timely sowing of rice. Directly seeded rice may mature 7 to 10 days earlier than transplanted rice (Subbaiah et al., 2002). The input requirement and investment in direct seeded paddy are much lower than in transplanted rice. "Srivastava 1986" reported a net saving of 147.5 man- hours and Rs 304/ha by use of paddy seeder over the conventional paddy transplanting. In the direct seeding method of rice cultivation, the need for a nursery and tasks such as pulling, transporting and transplanting of seeding are avoided as pre- germinated seeds are directly sown using a drum seeder in a well puddle and well leveled wet field. The drum seeder made of light fibre material little pulling force to operate, ambling one person to sow one hectare in 5-6 hours compared to 3-4 days of transplanting labour by 30-40 people in the case of traditional cultivation method. The need for hand weeding is reduced by use of pre- emergence weedicides coupled with use of a modified conoweeder in between the rows (Bala Hussain Reddy et al., 2011).

Therefore, direct seeding is becoming increasingly popular now days in India and adopted here for study. The direct seeding is further of two types' viz., broadcasting and row seeding by using drum seeder.

The direct seeding is grouped in to first, dry seeding i.e. dry seeds are directly seeded on the dry soil and second wet seeding i.e. sprouted seeds are sown in the puddle field. This study was performed in laboratory to check the constant seed rate under given distance travelled and to select the travel speed and suitable drum fill level of drum seeder in field evaluation.

This study was undertaken to investigate the effect of different drum fill level and travel speed of direct paddy drum seeder on seed rate, hill to hill spacing, number of seeds/hill, hill missing.

\section{Materials and Methods}

The implement drum seeder was used for sowing pre-germinated paddy seeds (24h soaking $+24 \mathrm{~h}$ incubation). The sprouted seeds are filled in the drums of seeder and single person pulls the seeds in the field. A laboratory calibration as well as field test was included in the testing of seeder. The laboratory calibration was performed to check the constant seed rate under given distance travelled and to select the travel speed of drum seeder in puddle field. The field performance test was carried out for the field capacity, field efficiency etc. in puddle field. 


\section{Location of study}

The laboratory Test calibration of the direct paddy drum seeder was carried out at Department of Farm Machinery and Power, Vaugh School of Agricultural Engineering and Technology, Sam Higginbottam University of Agriculture, Technology and Sciences, Allahabad, Uttar Pradesh. The field testing of direct paddy drum seeder was carried out at farmer's field at village Mohabbatganj, chaka Block of Allahabad District during kharif season.

\section{Preparation of pre-germinated paddy seeds}

Seed preparation for wet seeding, salt was mixed with water in the proportion of 1:10 (i.e. $100 \mathrm{~g}$ salt with 1liter water). Seeds were then soaked in salted water in bucket. After one hour lighter seeds and other impurities floating on the water were removed. Seeds were kept in the water for 24 hours. After 24 hours excess water in bucket was drained out.

The soaked seeds were placed in gunny bags and kept for next 24 hours. Length of sprout expected to be $1 \mathrm{~mm}$ to $2 \mathrm{~mm}$. The sprout lengths more than this limit will result in intervening of root and prevent free flow of seeds through the holes of the drums.

For increasing the temperature during the incubation, gunny bags were kept surrounded by paddy straw. Pre germinated seeds are shown in plate 2 .

\section{Calibration of direct paddy drum seeder}

The procedure of testing direct paddy drum seeder for correct seed rate is called calibration of direct paddy drum seeder. Metering laboratory test was used for calibration.

\section{Metering test in laboratory for calibration}

To determine the seed rates obtainable at different speed of travel and drum fill percentage. The series of test full, half, quarter capacity of the drum were conducted. The step by step procedure was as follows:

Determine the nominal width of coverage of paddy drum seeder. The nominal width is equal to the multiplication of the number of openings and the spacing between the openings. Find the length of strip, having the nominal width as determine below, necessary to make one hectare. Determine the number of revolutions the ground wheel has to make to cover the length of the strip determined below. It is recommended that this should be done by actually operating the paddy drum seeder in the same field and soil conditions as will be used for field operation test. Count the number of revolutions in a given distance, say 100 meters. A $60 \mathrm{~cm}$ diameter wheel will probably make about 53 revolutions in 100 meters. From the value found in below step 3 , select a number of revolutions of the ground wheel to cover a convenient fraction of a hectare, say $1 / 25$. A drum seeder having a nominal width of $1 \mathrm{~m}$ and ground wheel diameter of $60 \mathrm{~cm}$ will require about 212 revolutions to cover $1 / 25$ hectare. Calculate revolutions per minute of ground wheel in case of manually drawn seeder and revolutions per minute of metering device in case of tractor drawn seeding machine. The travelling speed for manually operated paddy drum seeder should be $1 \mathrm{~km} / \mathrm{hr}$. and for tractor drawn seeding machine the speed should be 3 and $5 \mathrm{~km} / \mathrm{hr}$. A $60 \mathrm{~cm}$ diameter ground wheel makes about 9 revolutions per minute when travelling at a speed of $1 \mathrm{~km} / \mathrm{hr}$. Practice running the drum seeder at the speed calculated in below step 5, if running has to be done manually for manually drawn direct paddy drum seeder. Select the pre germinated paddy seeds and place seeds in the drum. 
Either in static position with drive wheel above the ground turn drive wheel 50 turns and collect seed from outlets of the every drum. Weigh the quantity of seeds collected from each drum and calculate the seed rate $\mathrm{kg} / \mathrm{ha}$. Repeat the process at least three times.

\section{Calculation}

Effective width of direct paddy drum seeder

$\mathrm{W}=\mathrm{N} \times \mathrm{S}$

Where, $\mathrm{N}=$ No. of seed openings as rows

$\mathrm{S}=$ Spacing between two adjacent rows

Longitudinal distance to cover one hectare $=$ 10000/W

Longitudinal distance to cover $1 / 100^{\text {th }}$ of ha, in $\mathrm{m}$

Suppose the drive wheel of diameter D makes $\mathrm{N}$ number of revolution to cover $100 / \mathrm{w}, \mathrm{m}$

Therefore, $\mathrm{N}$

Seed rate $(\mathrm{kg} / \mathrm{ha})$

Where,

$\mathrm{W}$ is the weight of collected seeds in grams and $\mathrm{A}$ is the area in $\mathrm{m}^{2}$ covered by the direct paddy drum seeder,

\section{Uniformity of seeding}

Following sticky belt method was used to ensure the uniformity seeding device of the direct paddy drum seeder in which uniformity of seed spacing is the manner of placing of seeds. The uniformity of seed distribution is checked as; a bed of polythene measuring $15 \mathrm{~m} \times 1.6 \mathrm{~cm}$ was spread on the hard surface. The polythene was coated with white grease that helps in striking of seeds without rolling or bouncing on the bed surface. Direct paddy drum seeder was manually operated forward maintaining the speed of $1,1.5$ and $2 \mathrm{~km} / \mathrm{h}$. The seed metering system of the direct paddy drum seeder was set to place the pre germinated paddy seeds. Seed spacing of 100 - 100 seeds of pre germinated paddy were measured on the sticky bed to estimate the performance indices and to check the dropping pattern. The test was replicated three times and shows in plate 3 and 4 .

\section{Result and Discussion}

\section{Laboratory calibration}

The laboratory calibration of seeder at three different speeds and three different drum fill was performed to check the constant seed rate under given distance travelled and to select the walking speed for pulling seeder under field condition. The seeders were calibrated for three different speeds viz., $1 \mathrm{~km} / \mathrm{h}$, $1.5 \mathrm{~km} / \mathrm{h}, 2 \mathrm{~km} / \mathrm{h}$ and for initial drum fill percentage from full, half and quarter. The seeds collected after each fifty revolutions were weighed. From the observations, the graphs of distance travelled (m) vs. seed rate (sprouted seeds, $\mathrm{kg} / \mathrm{ha}$ ) for each percentage drum fill were drawn. Figure 1 of seed rate $(\mathrm{kg} / \mathrm{ha})$ vs. distance travelled 1 (m) shows that, the seed rate was nearly constant for initial $10 \mathrm{~m}$ distance travelled. For the next successive points i.e. up to $20 \mathrm{~m}$ distance travelled seed rate was observed increasing continuously. For the distance travelled from $9.4 \mathrm{~m}$ to $20 \mathrm{~m}$, the variation in the seed rate was found to be $5 \mathrm{~kg} / \mathrm{ha}$. Figure 2 shows that up to initial $6 \mathrm{~m}$ distance travelled the seed rate was nearly constant; for next $1.5 \mathrm{~m}$ distance travelled the seed rate was increasing continuously. For next $10 \mathrm{~m}$ travelled the seed rate was again found to be constant. For the distance travelled from $9.4 \mathrm{~m}$ to $20 \mathrm{~m}$, the variation in the seed rate found to be 4.5 $\mathrm{kg} / \mathrm{ha}$. Figure 3 shows that seed rate of the variation up to first $2 \mathrm{~m}$ distance travelled, 
was constant. For the next $6 \mathrm{~m}$ distance travelled, it was decreased and for further 12 $\mathrm{m}$ distance travelled seed rate was found to be increased continuously. For the distance travelled from $9.4 \mathrm{~m}$ to $20 \mathrm{~m}$, the variation in the seed rate was found to be $3.2 \mathrm{~kg} / \mathrm{ha}$. Figure 4 shows Average Missing index (\%) at different speed and drum fill level that seed rate was observed continuously increasing as distance travelled was increased. Also the variation of seed rate for each 5 revolutions of drum i.e. $9.4 \mathrm{~m}$ distance travelled was found to be less as compared to the other graphs. For the distance travelled from $9.4 \mathrm{~m}$ to $24 \mathrm{~m}$, the variation in the seed rate was found to be $8 \mathrm{~kg} / \mathrm{ha}$. Similar result was observed by Jinfu Geo and Te Ma (1977). Figure 5 indicates average hill to hill spacing at different speed and drum fill level up to $6 \mathrm{~m}$ distance travelled, seed rate was found to be nearly constant. For the next $14 \mathrm{~m}$ distance travelled it was increasing continuously and for further $9.4 \mathrm{~m}$ distance travelled it was constant. For the distance travelled from $9.4 \mathrm{~m}$ to $24 \mathrm{~m}$, the variation in the seed rate was found to be $10 \mathrm{~kg} / \mathrm{ha}$. Figure 6 shows that the average number of seeds per hill at different speed and drum fill level drastic change in the seed rate for $6 \mathrm{~m}$ distance travelled the seed rate was increased continuously. For the distance travelled from $9.4 \mathrm{~m}$ to $24 \mathrm{~m}$, the variation in the seed rate was found to be $13 \mathrm{~kg} / \mathrm{ha}$. Figure 7 shows that the seed rate was found constantly increasing and average variation in seed rate was also less. But it was for less distance travelled as compared to full and half drum fill level. For the distance travelled from $9.4 \mathrm{~m}$ to $12 \mathrm{~m}$, the variation in the seed rate was found to be $4.8 \mathrm{~kg} / \mathrm{ha}$ Figure 8 shows that drum fill level on hill to hill spacing least variation in seed rate was observed for $12 \mathrm{~m}$ distance travelled and it was $3 \mathrm{~kg} / \mathrm{ha}$ but it was for less distance travelled. Figure 9 shows that drum fill level on hill missing index continuous increases in seed rate also the variation in seed rate also the variation in seed rate from $9.4 \mathrm{~m}$ to $12 \mathrm{~m}$ distance travelled was found to be $2.5 \mathrm{~kg} / \mathrm{ha}$. Same was observed by Chavan et al., (2010).

\section{Plate.1 Complete view of direct paddy drum seeder}

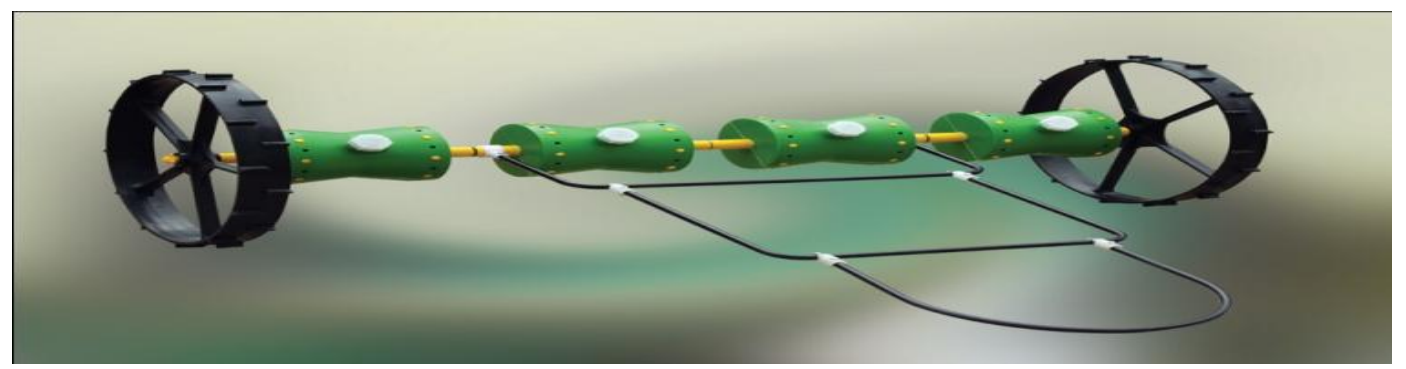

Plate.2 Germinated paddy seeds
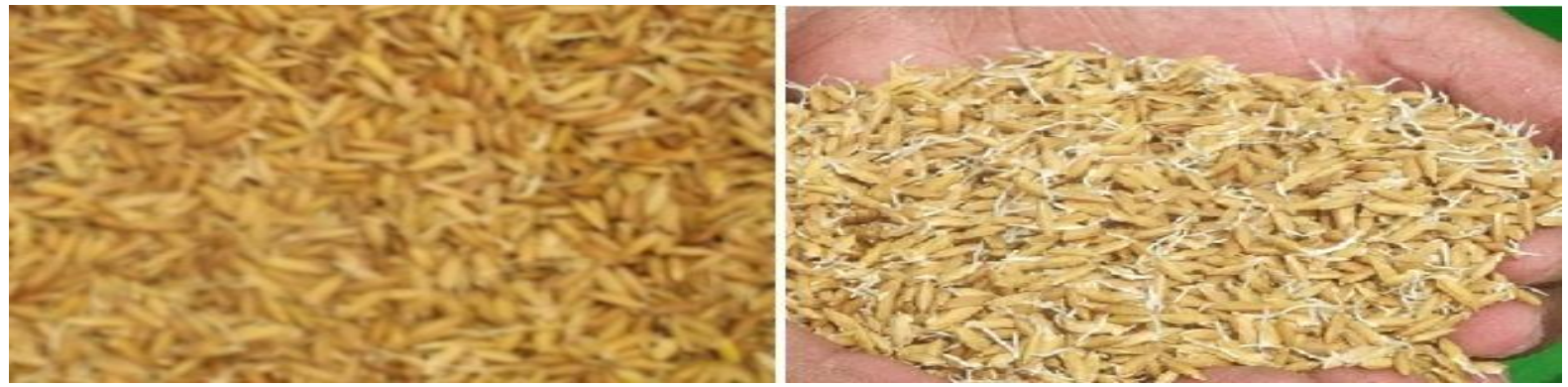
Plate.3 Hill dropping pattern of direct paddy drum seeder

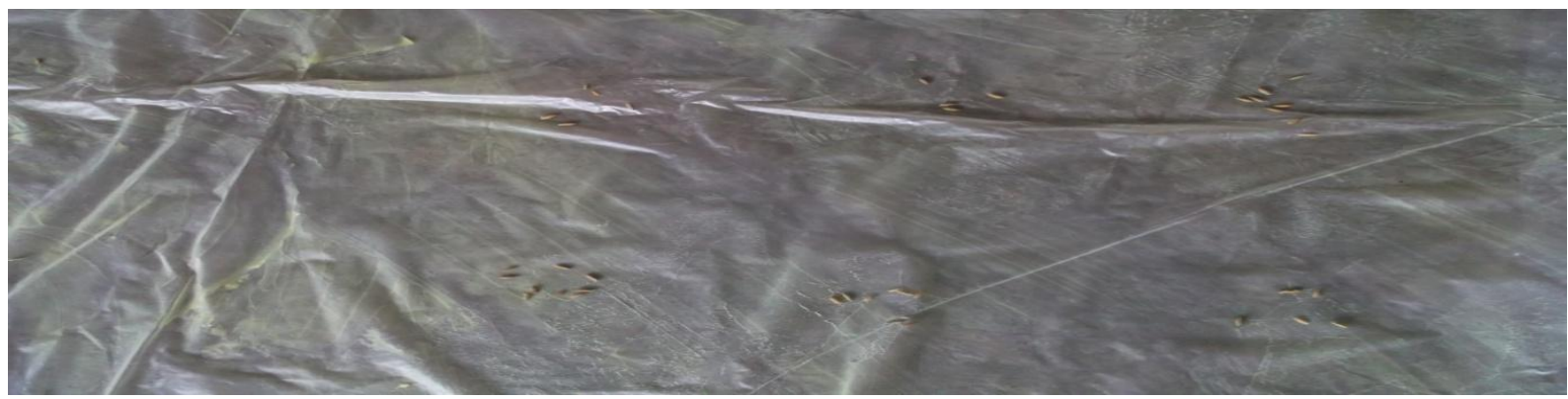

Plate.4 Measurement of hill to hill spacing for paddy seeds in the laborator

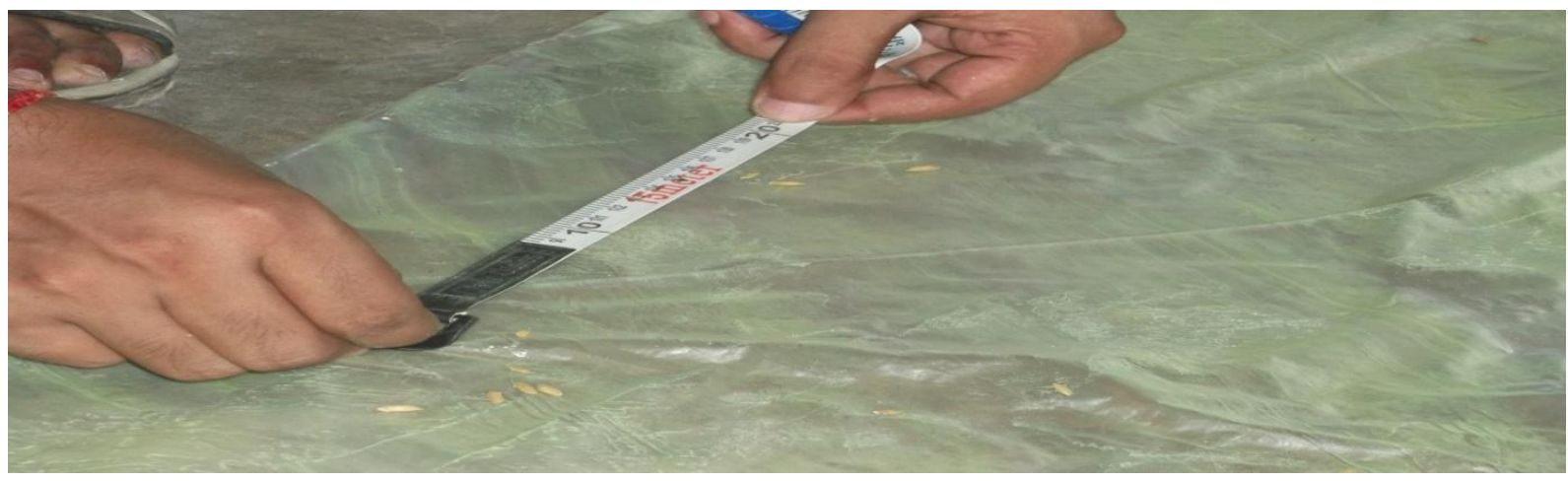

Fig.1 Variation of seed rate with distance travelled at full drum fill and $1 \mathrm{~km} / \mathrm{h}$ travel speed

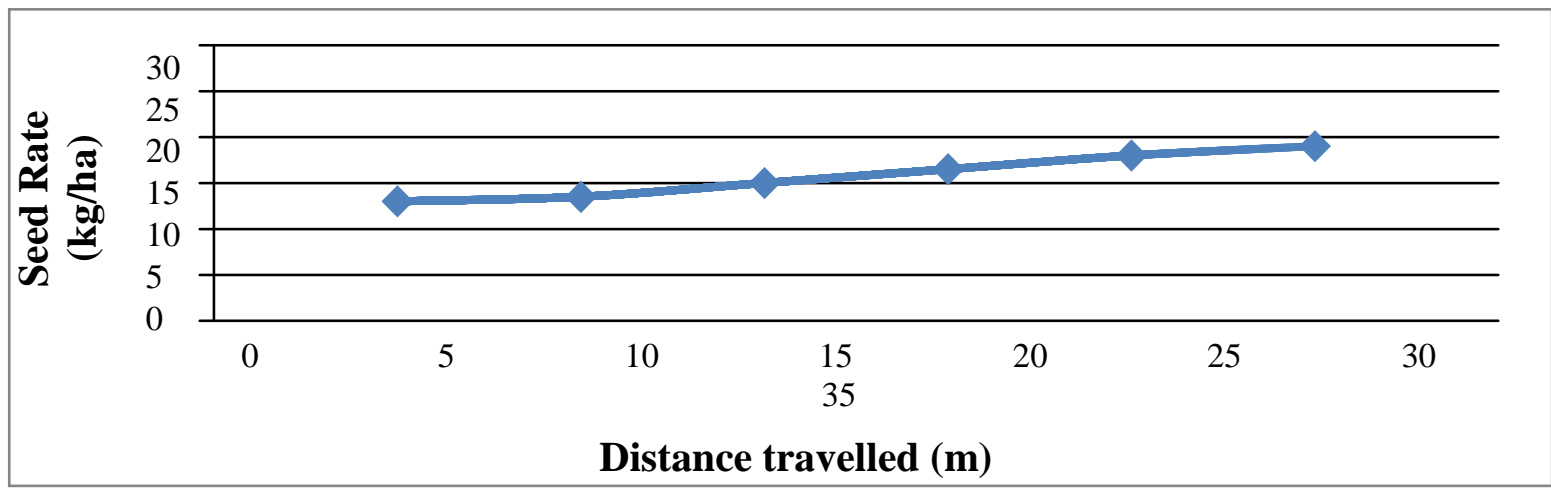

Fig.2 Variation of seed rate with distance travelled at full drum fill and $1.5 \mathrm{~km} / \mathrm{h}$ travel speed

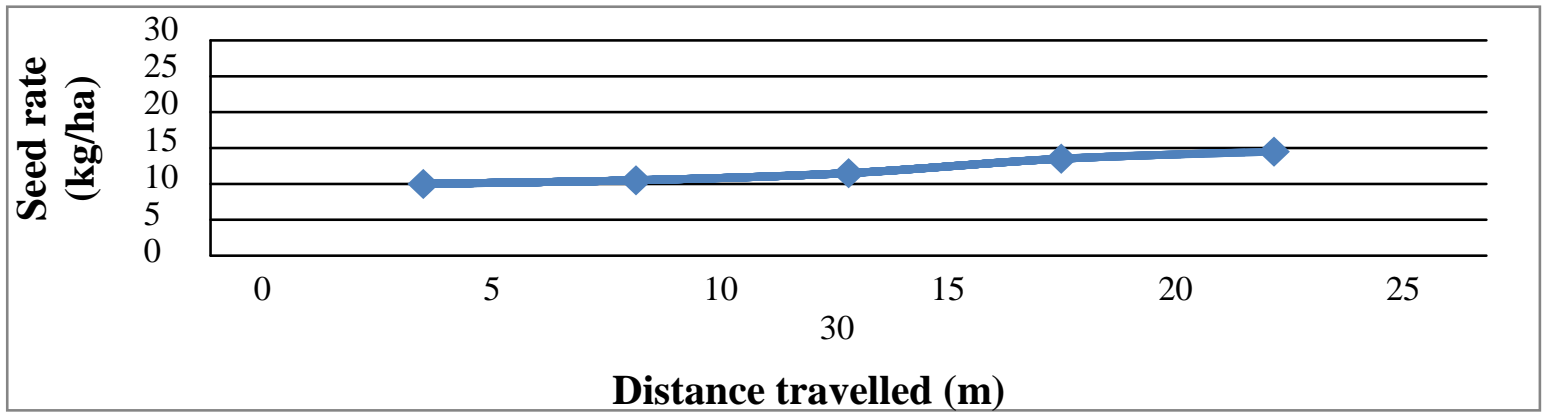


Fig.3 Variation of seed rate with distance travelled at full drum fill and $2 \mathrm{~km} / \mathrm{h}$

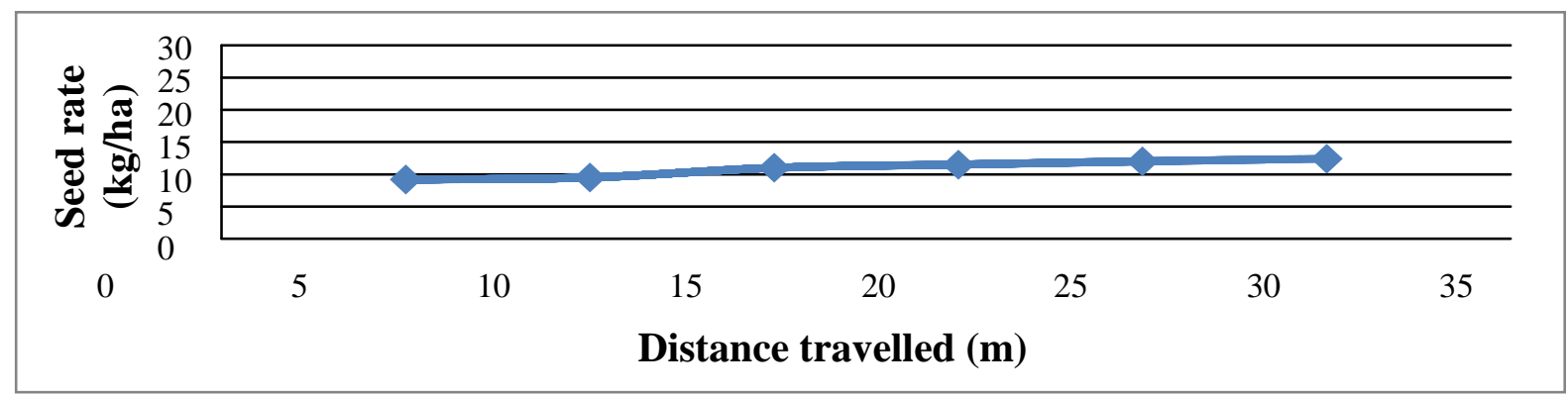

Fig.4 Average Missing index (\%) at different speed and drum fill level

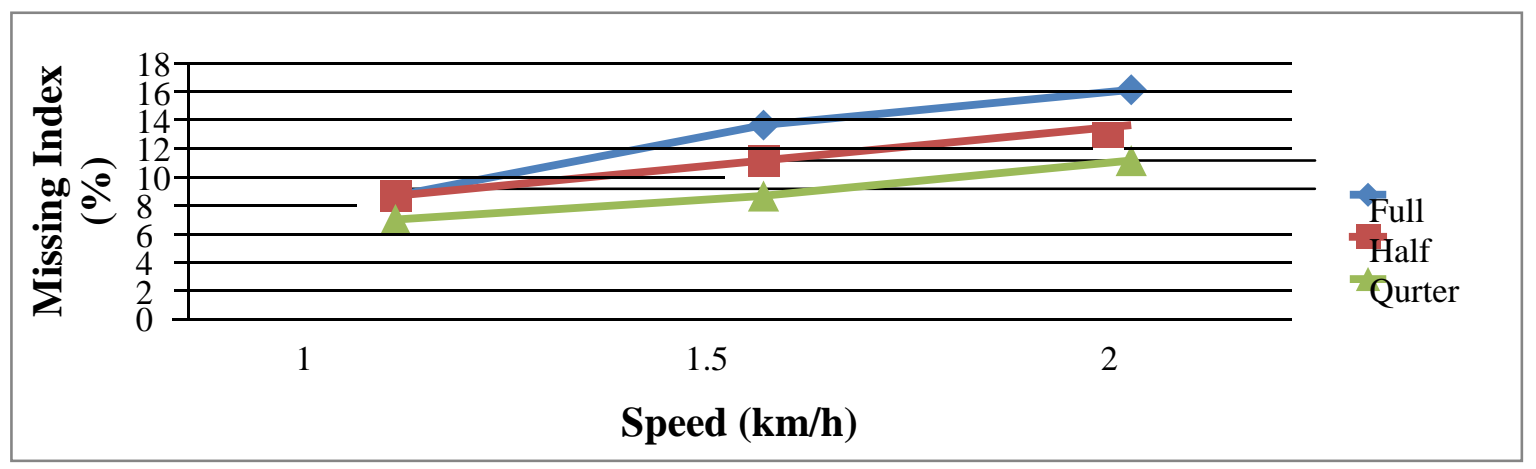

Fig.5 Average Hill to Hill spacing at different speed and drum fill level

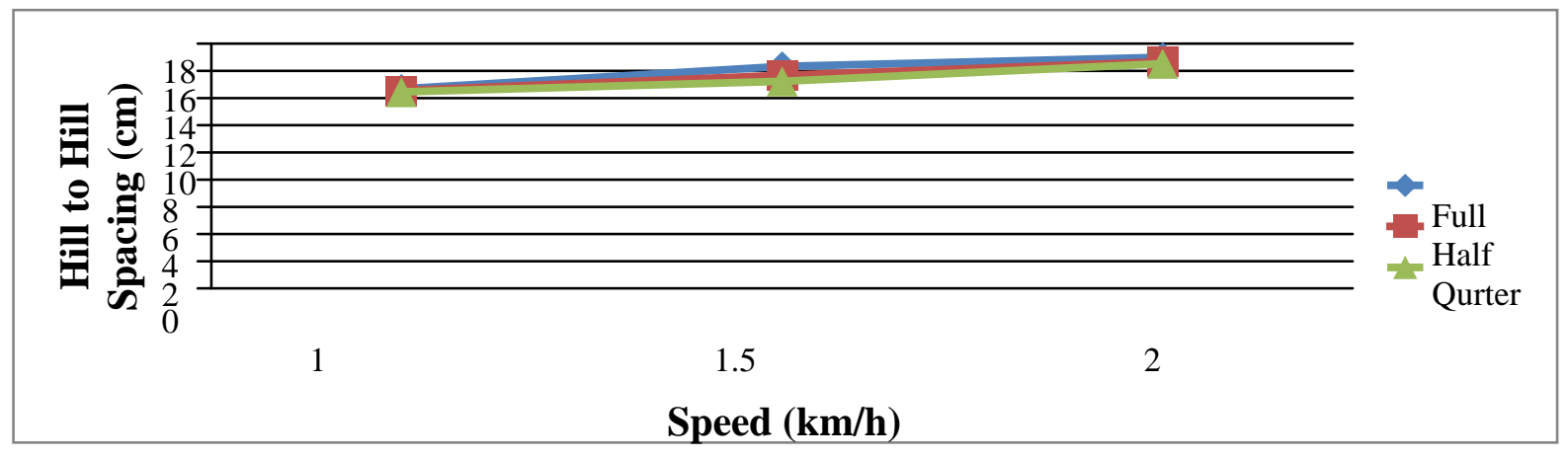

Fig.6 Average number of seeds per hill at different speed and drum fill level

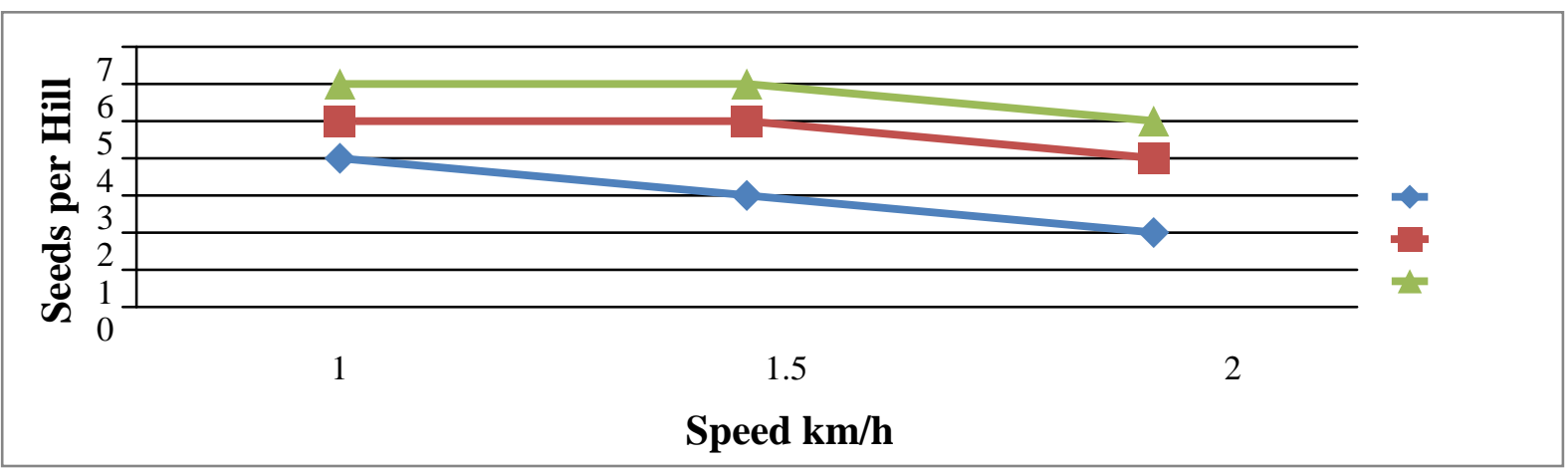


Fig.7 Effect of travel speed and drum fill level on seed rate

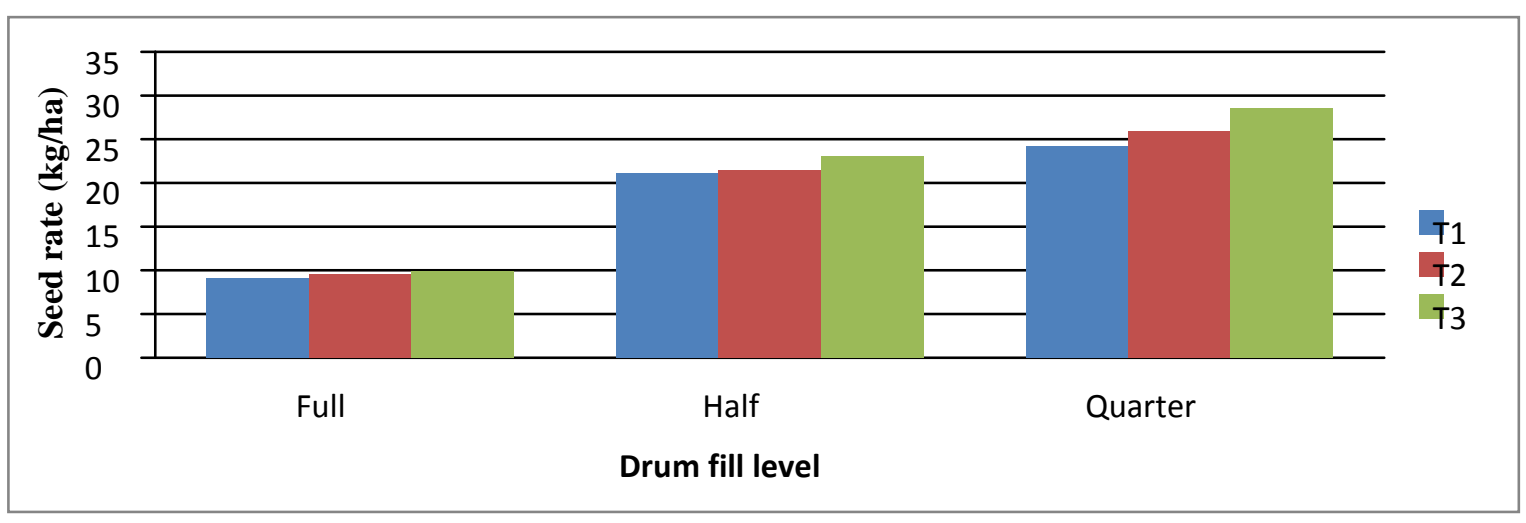

Fig.8 Effect of travel speed and drum fill level on hill to hill spacing

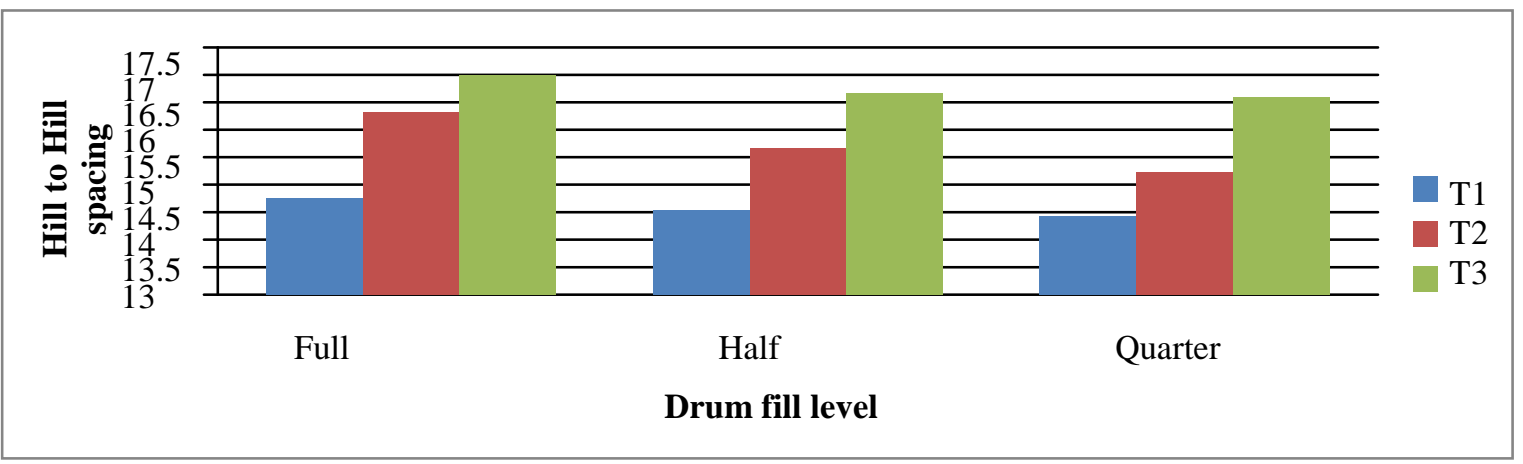

Fig.9 Effect of travel speed and drum fill level on hill missing index

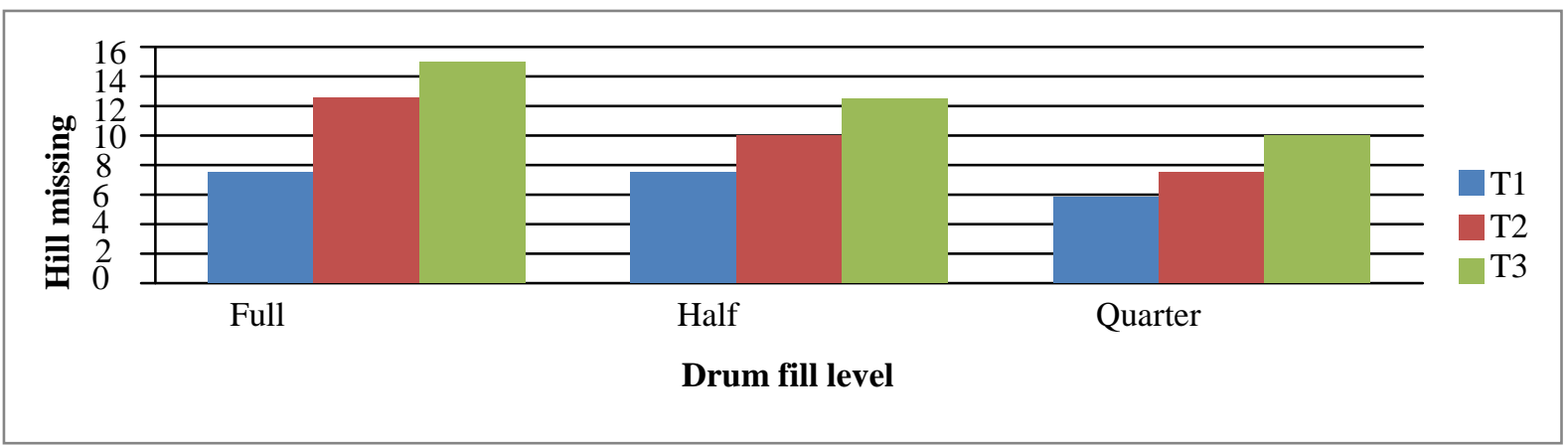

Table.1 Average number of seeds/hill for different drum fill and travel speed

\begin{tabular}{|c|c|c|c|}
\hline \multirow{2}{*}{ Speed $(\mathbf{k m} / \mathbf{h})$} & \multicolumn{3}{|c|}{ Drum fill level } \\
\cline { 2 - 4 } & Full & half & Quarter \\
\hline 1.0 & 9.09 & 21.16 & 24.16 \\
\hline 1.5 & 9.53 & 21.50 & 25.93 \\
\hline 2.0 & 9.93 & 23.05 & 28.59 \\
\hline
\end{tabular}


Table.2 Effect of drum fill level and travel speed of implement on seed rate, hill to hill spacing, seeds/hill and hill missing index

\begin{tabular}{|l|c|c|c|c|c|}
\hline $\begin{array}{l}\text { Drum fill } \\
\text { level }\end{array}$ & Treatments & Seed rate & $\begin{array}{c}\text { Hill to hill } \\
\text { spacing }\end{array}$ & Seeds /hill & $\begin{array}{c}\text { Hill missing } \\
\text { index }\end{array}$ \\
\hline Full & $\mathrm{T} 1$ & 9.09 & 14.67 & 4 & 7.5 \\
\cline { 2 - 6 } & $\mathrm{T} 2$ & 9.53 & 16.33 & 3 & 12.57 \\
\cline { 2 - 6 } & $\mathrm{T} 3$ & 9.97 & 17 & 2 & 15 \\
\hline Half & $\mathrm{T} 1$ & 21.16 & 14.53 & 5 & 7.5 \\
\cline { 2 - 6 } & $\mathrm{T} 2$ & 21.50 & 15.66 & 5 & 10 \\
\cline { 2 - 6 } & $\mathrm{T} 3$ & 23.05 & 16.66 & 4 & 12.5 \\
\hline \multirow{4}{*}{ Quarter } & $\mathrm{T} 1$ & 24.16 & 14.43 & 6 & 5.83 \\
\cline { 2 - 6 } & $\mathrm{T} 2$ & 25.93 & 15.23 & 6 & 7.5 \\
\cline { 2 - 6 } & $\mathrm{T} 3$ & 28.59 & 16.53 & 5 & 10 \\
\hline
\end{tabular}

\section{Seed rate $(\mathrm{kg} / \mathrm{ha})$}

The comparative performance of all combination at different drum fill level and travel speed is presented in tables 1 and 2 and figure 7 . The maximum seed rate was found to be $28.59 \mathrm{~kg} / \mathrm{ha}$ with T3 (seeding by drum seeder at the speed of $2 \mathrm{~km} / \mathrm{h}$ ) at quarter drum fill level. The minimum seed rate was $9.09 \mathrm{~kg} / \mathrm{ha}$ with $\mathrm{T} 1$ (seeding by drum seeder at the speed of $1 \mathrm{~km} / \mathrm{h}$ ) at full drum fill level. The treatment under study at different drum fill level and travel speed was found statistically significant at 5\% level of significant. Similar trends were observed by Sahoo et al., (1994).

From the study it was concluded that the combination of half drum fill level and 1 $\mathrm{km} / \mathrm{h}$ travel speed of direct paddy drum seeder was found to be suitable for operating the seeder in the field. The recommended seed rate for the variety under test i.e. kirtiman Hina was $25 \mathrm{~kg} / \mathrm{ha}$ for direct seeding. From the laboratory calibration the half drum fill level and $1 \mathrm{~km} / \mathrm{h}$ operating speed were found to give the average seed rate of 21.16 $\mathrm{kg} / \mathrm{ha}$ for pre germinated paddy seeds.

Actually in the field the seed rate observed was $27.5 \mathrm{~kg} / \mathrm{ha}$. The seed rate was found to be increasing during actual field operation this was may be due to jerks to the drum seeder resulting from uneven pulling of direct paddy drum seeder in the field (Singh et al., 1983). From the field performance test it was found that average number of seeds dropped per hill was 5. From the field performance test it was found that the hill to hill spacing was $14.5 \mathrm{~cm}$. From the field performance test it was found that the average number of hills per square meter was 30. From the field performance test it was found that the average hill missing was 5.8 percent. The effective field capacity of the direct paddy drum seeder was observed to be $0.131 \mathrm{ha} / \mathrm{h}$. The theoretical field capacity of direct paddy drum seeder was observed $0.16 \mathrm{ha} / \mathrm{h}$. The field efficiency of the seeder was found to be $82.08 \%$. The cost of operation of drum seeder worked out to be $42.67 \mathrm{Rs} / \mathrm{h}$ and 341.36 Rs/ha. 


\section{References}

Chavan Sumait, P., and Shwetambari M. Palkar 2010. Performance evaluation of paddy drum seeder. International Journal of Agricultural Engineering. 3(2): 279-287.

Devnani, R.S., Tayade, N. H., Thakare, S. K., Nikhade, J. S. 2010. Development and performance evaluation of manually pull type two row rice seeder for wet seedbed condition in India. International Journal of Agricultural Engineering, 2010. 3(2), 306311.

Islam Md., Syedul and Desa Ahmad 1999. Modification, test and evaluation of manually operated drum type seeder for low land paddy. Pertanika J. Science and Technology. 7(2): 85-98.

Jinfu Geo, and Te Ma 1977. Research and development of a new direct paddy seeder. Agriculture mechanization in Asia, Africa and Latin America, 28(3): 47-50

Khan, A.S., A. MAJID and S. I. Ahmad. 1989. Direct Sowing: An Alternative to Paddy Transplanting. Journal of Agricultural Mechanization in Asia, Africa, Latin America (AMA) Japan. 20(4): 31-35.

Khobragade, H.M., Kamble, A. K., Dave, A. K. 2012. Performance evaluation of pneumatic seed metering device for paddy in puddle. International Journal of Agricultural Engineering, 2012. 5(1): 98-102.

Majid Abdul Ahmed S.I., and Saeed M.A. 1989. Effect of different direct sowing techniques and date of sowing on rice production. Agriculture mechanization in Asia, Africa and Latin America, 20(3), 19-22.

Muthamilselvan, M., Manian, R., Kathirvel, K. 2008. Performance evaluation of basin lister cum seeder. Madras Agricultural
Journal, 2008. 95: 1/6, 129-140.

Pradan S.N., 1970. Drilling pre-germinated paddy on puddle land saver labour and yield more. Indian Forming, 19(10), 24-30.

Rao, V.V., Raddy G.H.S., Rao M.R. and Raddy T.B. 1973. Effect of different method of planning in the puddled on the yield of rice. Indian J. Agric. Sci. 43(6), 551-554.

Ratnayake, R. M. C., Balasoriya, B. M. C. P. 2013. Re-design, fabrication, and performance evaluation of manual conical drum seeder: a case study. Applied Engineering in Agriculture, 2013. 29: 2, 139-147.

Sahoo, P.K., Das D.K. and pradhan S.C. 1994. Development and testing of power tiller operated pre-germinated paddy seeder. Agricultural mechanization in Asia, Africa and Latin America, 25(1), 21-24.

Singh Sucheta, and Oliver Hensel 2012. On farm research on transplanting paddy: "BESTBET" prototype for drudgery reduction. International Journal of Agriculture Research and Review. Vol. 2(4).

Singh, R.D., Singh Bhagwan and Singh K.N. 1983. Evaluation of IRRI-Pantnagar Bullock- Drown Six-Row paddy seeder. Agriculture mechanization in Asia, Africa and Latin America, 14(3), 15-20.

Sirisha, D., Manian, R., Kathirvel, K. 2008. Development and evaluation of direct paddy seeder for assessing the suitability to rural women. AMA, Agricultural Mechanization in Asia, Africa and Latin America, 2008. 39(4): 41-45.

Srivastava, A.P., and Panwar J.S. 1988. Optimum sprout length for sowing pregerminated paddy seed in puddled soil. Agriculture mechanization in Asia, Africa and Latin America, 19(3): 43-46

\section{How to cite this article:}

Devesh Kumar, Uday Veer Singh, Jitendra Kumar, Manish Kumar and Kalay Khan. 2017. Laboratory Test and Calibration of Direct Paddy Drum Seeder for Pre- Germinated Paddy Seeds. Int.J.Curr.Microbiol.App.Sci. 6(9): 1037-1046.

doi: https://doi.org/10.20546/ijcmas.2017.609.125 